This is the version of the article accepted for publication in Historical Materialism published by Brill:

http://www.historicalmaterialism.org/journal

Accepted version downloaded from SOAS Research Online: http://eprints.soas.ac.uk/26363

\title{
Lineages of Capital
}

\author{
Alexander Anievas \\ and \\ Kerem Nişancıoğlu
}

\section{Introduction}

If this symposium tells us anything, it is that the 'transition debate' remains alive, well and hotly contested! And so it should, considering what is at stake in how we politically and theoretically navigate capitalism, not only in its past but also its present. It is perhaps a testament to the centrality of the problems bound up in the transition debate that the contributions to this symposium are so searching. More so, it is a testament to the quality of our interlocutors' work that these problems have received such thoroughgoing examination. We are privileged and grateful for the serious, critical and productive engagements offered by each of the authors in this symposium.

Such is the breadth and depth of these contributions that our response is, regrettably, partial. In particular, there are numerous disagreements over characterisations and interpretations of the historical material we handled in the How the West Came to Rule (HWCR) which require considerably longer engagements than what we can offer here. There are also various original contributions that help 'thicken' what historical material should be included in this debate. Finally, there are important calls to broaden the research programme to include 
jurisdictional accumulation (Pal), the 'biography of one product' (Banaji), and 'articulation' (Medved). Together, such contributions demonstrate the value of productive disagreement.

For these reasons, our reply focuses on some key themes that have emerged in the course of this symposium where our disagreement has been less productive, where we are perhaps talking past each other, and where it appears we have collectively become cemented into intractable and irreconcilable positions. We hope in engaging with these subjects we might offer readers new ways of thinking through the differences in our respective positions.

There are three key themes we explore. In the first section, we discuss an enduring issue in Marxist International Relations: 'the problematic of the international' and the problems of methodological internalism. We examine how our interlocutors have responded to this problematic and why we consider these responses insufficient. In particular, we suggest that the source of our disagreement is grounded in two divergent understandings of the problem of internalism itself. In doing so, we reassert the value of our chosen response to the problematic uneven and combined development (UCD). In the second section, we explore the tensions identified by our critics in this use of UCD. More specifically, we respond to the criticisms that our extension of UCD as a 'transmodal' general abstraction is problematic by further explicating the significance and role of general abstractions in Marxist theory - a point yet addressed by our critics. In the third section, we return to the fundamental question at the core of the transition debate: what is capitalism and how do we theorise it? Here, we re-situate the problem in terms of how we understand and theorise social relations that are not reducible to the capital relation. We argue that using UCD allows us to identify and understand how the multiplicity of social relations and 
historical processes combine in order produce and reproduce the capitalist mode of production. We argue that such an understanding helps shed light on how different forms of violence, oppression and exploitation - and the struggles around them - relate to capitalism and the resistance to it.

\section{The 'Problematic of the International'}

A key concern in HWCR was not only empirically tracing but also theorising the role of intersocietal relations as constitutive of the making of capitalism. We argued that it was this missing intersocietal component of the existing historical sociology on the topic that had kept it so hamstrung and resolutely Eurocentric. In doing so, we suggested that extant accounts - especially Political Marxist approaches - fell prey to the trap of methodological internalism. As such, Political Marxism was unable to provide an adequate theorisation of relations between societies and offer a truly 'international historical sociology' of capitalism's emergence.

Spencer Dimmock and Maia Pal's contributions to this symposium contest this claim, by arguing that Political Marxism's conception of 'social property relations' can and does provide an adequate response to 'the problematic of the international'. This is because social property relations capture a three-way dialectical relationship: (1) the interaction of humans with nature; (2) the exploitative relation between the direct producers and their surplus-appropriators, and; (3) the relations within and between the ruling classes (Dimmock xxx; Pal xxx; Post: xxx). Given that 'classes, particularly ruling classes, do not simply compete, go to war, or collaborate or trade with one another within the boundaries of their respective polities, countries or nations', we are told social property relations 'fully encompass inter-societal interaction and the influence of 
that interaction on the reproduction or transformation of those relations' (Dimmock XXX). As such, these property relations are not 'limited a priori by internal or external conditions', nor confined to a single society, but are rather 'central for the construction of political spatiality' itself (Pal xx).

However, these responses betray a misunderstanding of our uses of internalism and are therefore an inadequate response to the 'problematic of the international'. We take internalism to mean, firstly, the methodological commitment to understanding the origins and expansion of capitalist modernity as a product of developments endogenous to Europe. Conceptualising social change as an immanent property of societies, Eurocentric internalism locates the emergence of capitalism exclusively within the hermetically-sealed and socio-culturally coherent geographical confines of Europe. As a result, Europe is transformed into the permanent 'core' and 'prime mover' of world history and the model from which all other forms of development are contrasted and judged (HWCR: 4-5).

Implicit in this conception is a second, more traditional, understanding of internalism or 'methodological nationalism': the conflation of society with a particular nation or territorial state as the primary 'unit of analyis'. Both of these meanings of internalism have specific spatial registers (Europe; the nation-state) and 'inside-out' logics of causality (from 'Europe to colony A'; from 'England to colony A') as Pal correctly notes.

There is, however, a third way we understand internalism that is foundational to our argument - the problem of 'ontological singularity'. ${ }^{1}$ This refers to the assumption that by working outward form a theory of a single social structure (for example, slavery, feudalism, capitalism, etc.)

\footnotetext{
${ }^{1}$ Rosenberg 2006.
} 
one may arrive at a theoretical conception of multiple societies. An implicit assumption of this method is that differences between social structures and their interactions are not accorded any analytical or explanatory value. In short, societal difference does not factor into a theoretical conception of 'the international': hence our critique of Immanuel Wallerstein for subsuming intersocietal determinations under an 'overriding operative logic of a singularly-conceived world-system' (HWCR: 16). The argument is not that inter-state relations and geopolitics are unimportant to Wallerstein's analysis or theory. Instead, our critique is that, as Mladen Medved puts it (XX), the 'concept of the intersocietal is unthinkable in Wallerstein as the capitalist world-system is one society'.

In contrast, Pal transforms our quantitative conception of sociological singularity (in Political Marxist terms 'feudal social property relations', 'capitalist social property relations') into a qualitative one that refers to a historically specific articulation of political spatiality; that is, states with clear inside/outside demarcations of the type only found in the capitalist epoch. Similarly, Dimmock (XX) mischaracterises UCD as a 'geopolitical theory'. These important slippages allow Pal and Dimmock to counter our criticism that Political Marxism is methodologically internalist since social property relations is not 'limited a priori by internal or external conditions' and encompass relations within and between individual states (Pal XX). But 'multiple territorialities' or 'multiple jurisdictions' (Pal XX, emphasis added) are not the same as multiple (and differentiated) societies, as the former can be predicated on the same singular type of social property relations.

Put differently, the problem of internalism is not simply a question of the character of political spatiality. It lies instead with the very fact of quantitative and qualitative multiplicity itself: that societies are plural and different. That the problem of - and solution to - internalism is conceived 
in terms of how political space is organised suggests proponents of UCD and social property relations are talking past each other when it comes to the 'problematic of the international'. To say social property relations can 'encompass inter-societal interaction' or include 'geopolitical dimensions' does not meet the stronger demand we make of historical sociology - that it must include the intersocietal as an ontological premise that is irreducible to any particular set of social relations.

It is in light of this stronger demand that we find Political Marxist accounts lacking. For example, a particularly clear statement of Political Marxism's methodological internalism in the sense described above is provided by Benno Teschke, whose work is explicitly marshalled by Pal in making her counter-critique. In his landmark treatise, The Myth of 1648 , Teschke writes:

My core theoretical argument, developed by elaborating the principles of political Marxism, is that the constitution, operating, and transformation of geopolitical orders are predicated on their constitutive units. Social property relations, mediating the relations between the major classes, primarily define the constitution and identity of these political units. The time-bound balances of social forces find expression in politically constituted institutions...that set the parameters for class-specific, and therefore antagonistic, rules of reproduction. ${ }^{2}$

Equally, Robert Brenner is quite clear regarding the causal sequencing of his deductive model: 'form of property relations $\rightarrow$ rules for reproduction of the individual economic actors $\rightarrow$ long-term pattern of economic development/non-development'. ${ }^{3}$ Given that 'political accumulation' is

\footnotetext{
2 Teschke 2003: 7.

${ }^{3}$ Brenner 1986: 26-27.
} 
conceived by Brenner as a particular kind of 'rule of reproduction', ${ }^{4}$ feudal geopolitics are thus conceptualised as a specific expression (not expressions) of a particular form of social property relations. In other words, geopolitics is reduced to an ontologically singular conception of 'the social'.

These influences are not lost on our contributors; we see reiterations of such internalism when Dimmock, Post, and Pal engage with our substantive historical arguments. For example, we are told by Dimmock $(X X)$, following Brenner's comparative analyses of medieval and early modern Europe, that

unless a particular society or country is conquered, and a new set of socialproperty relations are installed by the conquerors, the established socialproperty relations - and the outcomes of vertical and horizontal struggles therein - will be determinate in the face of external pressure. In other words, the nature of the response to this pressure, and consequent outcome of this response, will depend upon the nature of the social-property relations.

Similarly, Charles Post $(\mathrm{XX})$ takes us for task for losing sight of how the impact of intersocietal interactions and competition 'are always filtered through the dominant social property relations and class conflicts within a given society'. Pal suggests $(\mathrm{XX})$ that the concept of geopolitical accumulation is not derived from an 'ontologically singular form', but does not show how it is - or rather must be - ontologically multiple. In turn, she argues that 'internal jurisdictional conflicts play a much stronger role in determining concepts of sovereignty'. Despite the insistence that the social property relations approach need not be internalist, it appears we are back to internal relations being 'determinant' in the final instance.

${ }^{4}$ Brenner 2007: 71. 
In this respect, the exact theoretical issues arising from the 'problematic of the international' has somewhat eluded our interlocutors. Or, more likely, they would simply reject the premise of the problematic itself. ${ }^{5}$ Indeed, perhaps a Political Marxist would argue that the international' can only be understood in terms of its constitutive units, themselves predicated upon historically-determinant social property relations. This is of course a legitimate response, and we can debate the merits of the 'problematic of the international' and whether it does add something to understanding the origins of capitalism or any other subject. Nonetheless, it is incorrect to claim that Political Marxism provides an answer to the problematic which UCD is aiming to address or dismiss our criticism of the absence of such a theory in Political Marxism as 'wholly inaccurate' or a 'misrepresentation of the social property relations approach' (Dimmock XX; Pal XX). Such a response simply represents a misunderstanding of the problematic and what is at stake in addressing it.

In particular, we would insist that working outward from a specific set of social property relations (say, feudalism) can never fully explain the dynamics and interactions between different sets of social relations. And, moreover, there will always remain a 'surplus' of lateral determinations arising from these intersocietal relations that are irreducible to any particular social structure. Without a theorisation of this intersocietal dimension of development, societal multiplicity is continually encountered as a phenomenon external or contingent to our theoretical premises, no matter how much empirical weight it may hold in concrete historical explanations. It is in this sense that 'the international' appears as an adhoc untheorised addendum to an otherwise internalist analysis: it 'enters

\footnotetext{
${ }^{5}$ Pal's contribution comes closest to this position. Similarly, it is revealing that whereas Dimmock and Pal seek to defend Political Marxism's ability to theorise 'the international', Post is more circumspect.
} 
stage-left, as a fully-formed determination whose origin is unexplained'. ${ }^{6}$ Put differently, the concept of social property relations itself does not provide a theorisation of 'the international' as its own distinct and irreducible social domain. The international is, in other words, always derived or reduced to extant social property relations. While one might be able to show how social property relations can identify intersocietal processes, it does not contain within it the methodological premises to theorise such processes in a non-reductionist way.

In short, the problem goes beyond simply incorporating intersocietal relations as an 'intervening dimension'7 of concrete explanations of sociohistorical developments. It instead requires a reformulation of historical materialism's foundational ontology in order to provide a substantive theoretical conception of that dimension of social reality which arises specifically from the coexistence within it of more than one society. ${ }^{8}$ Following Kamran Matin, we argue that this demands a reconceptualisation of Marx and Engels' 'double relationship' as a 'triple relationship' encompassing humans' relationship to: (1) nature; (2) the social, and; (3) the intersocietal. ${ }^{9}$ In $H W C R$, we sought to draw on Trotsky's idea of UCD to fashion such a social theory of 'the international' without losing sight of the ways specific articulations of UCD only operate in and through distinct modes of production; hence, our conceptualisation of UCD as a 'transmodal' phenomenon. This then breaks with the false yet obstinate separation of 'sociological' and 'geopolitical' modes of explanation common to social and IR theories alike. But here we encounter an additional objection: that UCD is only applicable to capitalism and that any wider extension of UCD inevitably results in

\footnotetext{
${ }^{6}$ Davidson (2010: 81) in a critique against the 'two logics' theory of imperialism.

7 Teschke 2005: 12.

${ }^{8}$ Rosenberg 2006: 308.

${ }^{9}$ Matin 2013.
} 
ahistorical arguments or descriptive trivialities. We now turn to address these claims.

\section{Lineages of Uneven and Combined Development}

Our extension of UCD to the pre-capitalist epoch is challenged by Neil Davidson and Charles Post, even though they both accept that unevenness is a general feature of world history. What they reject is that Trotsky's 'universal law' of uneven development leads to 'combination' prior to the emergence of capitalism, but do so for rather different reasons. For Davidson, the problem with our conception of UCD as a 'general abstraction' is primarily two-fold.

First, Davidson argues (XX) that the radically differentiated form intersocietal relations takes depends upon specific historical eras, and that this means 'they cannot be subsumed in all their variety under a single "general abstraction"'. Yet much hangs on what kind of analytical work a 'general abstraction' is supposed to be doing in theory. If the function of a general abstraction is to explain a given phenomenon, then surely Davidson is correct. But this is not, we argue, what a general abstraction is supposed to 'do'. Rather, a general abstraction functions as an in-built assumption that identifies the existence of a general condition whose historically-distinctive form must be accounted by additional explanans. Here, the role of a general abstraction is to isolate particular objects of study and open up them up further investigation. This in turn raises new analytical questions that can only be answered through their connection to other abstracted 'moments' and concretised through rich historical contextualisation and analysis.

Hence, the sheer variety of concrete instantiations of a general condition is exactly what we should expect a 'general abstraction' to 
identify. For example, Marx's abstraction of 'production in general' identifies a universal condition of social existence that takes radically different forms dependent upon different historical epochs. As a result, the contemporary form production takes under capitalism, can only be explained through more concrete determinations and abstractions (e.g. 'abstract labour', 'exchange-value', etc.). If Davidson agrees (XX) that the 'whip of external necessity' and 'privileges of backwardness' are general conditions of the unevenness of historical development, on the one hand, and consequently that 'societies are likely to embody fusions of quite different institutions and practices, drawn from different levels of development', on the other, then we would argue that UCD can be said to operate at a transmodal level.

This leads to Davidson's second point of criticism. That 'combination' in Trotsky's original meaning of the term is much more specific; that it refers to the 'fusion of "backward" and "modern"' forms derivative of the 'immense difference' between industrial capitalism and pre-capitalist societies wherein 'the moment the former was introduced, combination became possible in a way that it had not been hitherto'. Consequently, once industrial capitalism emerged, 'combination became inescapable, as all aspects of existing society registered the impact on them, to differing degrees, of this radically new means of exploitation' (Davidson XX).

Perhaps surprisingly, we are in complete agreement with Davidson on this point and have made nearly identical claims ourselves (HWCR: esp. 61-63). ${ }^{10}$ None of these claims, however, invalidate the legitimacy of deploying UCD to pre-capitalist periods, so long as one recognises, as we and Davidson suggest, the very significant qualitative differences between

${ }^{10}$ Anievas and Nişancıoğlu 2013: 100-101. 
capitalist and pre-capitalist forms of UCD. At this point, the argument appears to be over semantics: whether 'uneven development' can fully capture the range of phenomena we seek to cover under the rubric of uneven and combined development.

Yet this view is only partly correct, as there remains one substantive point of disagreement between Davidson and ourselves. This revolves around an empirical debate over the importance and extent of varieties of pre-capitalist social relations. Davidson argues that pre-capitalist agrarian societies were only differentiated at the level of the state and intra-ruling class relations that existed on a spectrum ranging from feudal to tributary modes of production. He thus rejects notions of a 'nomadic' or 'slave' mode of production. 'Because of these underlying similarities it was possible for societies to borrow from each other and for the borrowings to be fully absorbed', meaning that it is only with 'the dawn of the capitalist era that "combination" actually leads to the possibility of "development" that is, of moving beyond the essentially static interchanges between different pre-capitalist societies' (Davidson XX).

The issues raised by Davidson here constitutes a much more substantive challenge to the more general conception of UCD we apply to the pre-capitalist era, and there is much to debate here that lies beyond the scope of this reply. But even if we accept Davidson's argument that there essentially existed only two forms of (tributary and feudal) class societies before capitalism and we accept that a combined development can occur within a single mode of production, as he does, then the historical record offers myriad examples of intersocietal exchanges generating forms of 'combinations' leading to 'development'. Kaman Matin's study of premodern Saffavid state formation, for example, demonstrates how the underdevelopment of private property in land was a consequence of Saffavid's continuous engagement with its nomadic 
neighbours. The resulting state-form was, however, irreducible to either polity, taking a 'non-singular character' that Matin terms an 'amalgamated state formation' - a consequence of a 'dynamic, internationally generated combination (and not merely assimilation or external tributary relations) of the nomadic and agrarian polities in premodern Iran'. ${ }^{11}$ Our own analysis of the Ottoman Empire points in a similar direction, as does our more recent examination of the formation of the Mughal Empire that draws upon and extends arguments first made in $\operatorname{HWCR}(91-120,263-269) .{ }^{12}$ In all these cases, the interaction of tributary and nomadic societies resulted in dynamic political forms that were irreducible to either polity. These intersocietal exchanges - most dramatically expressed through military conflict and war - were thus constitutive of the changing, amalgamated forms they took. They were, in short, a force of combined development.

For Post, however, a combined development is restricted even further. It is exclusively associated with 'the introduction of the capitalwage-labour relation and the systematic development of labourproductivity through labour-saving devices' that only occurs after 'the advent of industrial capitalist production' (Post XX). The most immediate problem with this formulation is Post's identification of combined development with the specific form of capitalist-driven combined development. By defining combination in this way, the historical possibility of non-capitalist forms of combinations is ruled out a priori. Given Post's definitional conflation of combination in general with the particular form of combined development under capitalism, he is able to argue that our conception of UCD in explaining the rise of capitalism reproduces the errors of the "commercialisation model"-assuming the existence of

\footnotetext{
11 Matin 2007: 438.

12 Nişancıoğlu 2016; Anievas and Nişancıoğlu 2017.
} 
capitalist rules of reproduction to explain the emergence of capitalist property relations' (Post XX).

Post does not, however, provide any textual evidence from HWCR to back-up this claim. And, for good reason: none exists. Throughout the text, we are at pains to emphasise how the operation of UCD is conditioned by and articulated through historically-distinct forms of social relations and processes: thus our discussions of feudal, tributary, nomadic, and slave-based modes of productions and their corresponding 'rules of reproduction' vis-à-vis the differentiated dynamics of UCD. Post's $(X X)$ entire argument regarding the inapplicability of 'combined development' to the pre-capitalist epoch rests on his assertion that '[p]recapitalist geopolitics did not lead to systematic economic development in those societies incorporating new methods of production'. Such precapitalist intersocietal interactions instead 'tended to undermine economic development because of the relative stagnation of laboursaving technological development before capitalism'.

But Post's argument here is yet again left as an assertion that lacks any empirical or even citational substantiation. Nor does Post engage with the mass of evidence detailing the substantial technological and social developments we provide in $H W C R$, which draws on the latest historiographical literatures on late Medieval and early modern world history. What we sought to demonstrate there was that the idea that developments in the productive forces were 'highly episodic' and often took a 'once and for all' (Post XX) character before capitalism was based on a one-sided and now largely discarded conception of pre-capitalist development. ${ }^{13}$ And, moreover, that such processes of technological and

\footnotetext{
${ }^{13}$ For overviews, see Allen 2000, Wickham 2008, and Persson 1991 and 2014. We therefore agree with Davidson's (XXX) contention that the feudal and tributary modes of production entailed an immanent tendency to develop the productive forces. What the theory of UCD nonetheless demands is that this conception of 'immanence' must incorporate both relations within and between societies. To
} 
social dynamism in pre-capitalist societies were often a response to the pressures and opportunities generated by intersocietal dynamics.

We show in Chapters 3 and 4, for example, how the tributary practice of 'caging'14 allowed for the absorption of techniques, capacities and organisational forms of disparate societies into an integrated and dynamic system of ruling class reproduction that entailed significant developments to the productive forces. In Chapters 5 and 7, we further analyse how capitalism was built on the combination of a multiplicity of labour processes in various locales stretching from Barbados to Banda, back to London and Amsterdam. It is also important to note that the imposition of new - or reconstruction of old - social structures as a result of war and conquest is much less uncommon in history than Political Marxists have argued, particularly in the case of colonial conquests and wars. Indeed, the twin processes of imposition and reconstruction often go together as exemplified in the post-1492 Americas and early modern Southeast Asian colonies (HWCR: Chapters 5 \& 7).

Post's claim $(X X)$ that our theoretical development of UCD introduces so much contingency into the historical analysis that it makes our arguments 'waiver between simple description and causal indeterminacy' is, therefore, based on the above-noted misapprehension of the theory: one that again identifies UCD with an exclusively 'geopolitical' mode of explanation. This is evinced in Post's argument regarding the differential sociohistorical impact of the demographic collapse following the Black Death that is presented as a refutation of our own theorisation of the process. This is so because, according to Post, we do not account for

\footnotetext{
take just one example: the dynamism of Ottoman tributary relations was fundamentally dependent upon developments in agrarian production in support of geopolitical accumulation and vice versa (HWCR: 99-104).

${ }^{14}$ That is to say, the dual process whereby, on the one hand, territories conquered by tributary empires would assimilate tributary social relations into their own pre-existing forms while, on the other hand, the conquering tributary state would habitually absorb the local customs, laws, forms of social organisation, and individuals of the conquered territories (van der Pijl 2007: 63, 67; cf. HWCR: 70, 102-103).
} 
these differences. Yet this is not the case. In $H W C R$, we draw upon Brenner and other scholars' analyses of the ways in which the demographic collapse was highly uneven (both socially and geographically) as its effects were mediated and conditioned by the variegated balances of class forces within and across different European societies. ${ }^{15}$ Since no textual evidence from $H W C R$ is provided by Post to substantiate his claim that we argue otherwise, forgive us for quoting ourselves at length to put the matter to rest:

the long-term agrarian revolts precipitated by the Black Death spurred variegated forms of revolution and counter-revolution around seigniorial rule, re-ordering feudal social relations in ways that it would eventually prove unable to recover from. Where seigniorial reaction was successful, however, depended on the balance of class forces and antecedent processes of internal differentiation (88, emphasis added).

The last point concerning the significance of these differences in the balance of class forces and processes of internal differentiation are examined earlier in the chapter where we primarily focus on developments within England where the Black Death most notably hastened the demise of the old feudal order (HWCR: 79-85). We then go on to explicate a key reason behind these divergent outcomes between Western and Eastern Europe in general, specifically the variegated relations between land and labour in these regions, and then re-state Brenner's thesis regarding the differential paths of development between England and France in particular (HWCR: 88-90). Perhaps we should have flagged our discussion of Brenner's thesis earlier and provided a more detailed empirical examination of these processes given that this has been a

${ }^{15}$ See further, Anievas and Nişancıoğlu 2016b. 
source of confusion in other reviews of our work. ${ }^{16}$ Nevertheless, it is there. ${ }^{17}$

It would appear, then, that Post's (XX) charge of 'causal indeterminacy' derives from the mere fact that we reject the 'analytic primacy of social property relations and class conflict' and, therefore, refuse to provide any 'ordering of determinations' at the 'heart of materialist social theory'. But the latter does not follow from the former. That is to say, one can certainly reject the 'analytic primacy' of social property relations - here referring to internal social relations - without giving up the idea that some determinations are more important than others.

Indeed, we conceive the role of class struggle and changes in the relations of production as absolutely fundamental to theoretically explicating the rise of capitalism. But, crucially, we do so by conceptualising these developments within their wider intersocietal contexts demonstrating the structural connections between them in a way that transcends any conception of 'the international' as simply 'contingent'. From the perspective of UCD, the peculiarities of any given society's development are a necessary (albeit highly variegated) outcome of this broader intersocietal milieu. As diverse and differentially situated societies interact, they continuously impact upon one another's

\footnotetext{
${ }^{16}$ See Bieler 2016; Braude 2015.

17 Similarly, Post's $(X X)$ more general claim that our 'assessment of the relative weight and impact of different "vectors" [of UCD] are historically problematic, and often simply inaccurate' rests on a number of important confusions regarding other historical arguments we make. For example, Post takes issue with our claim that the de-militarisation of the English nobility - a significant factor cited by Brenner and others in the development of English agrarian capitalism - was a result of the country's relative 'geopolitical isolation' that was a distinctly intersocietal condition arising from the European continent's preoccupation with the Ottoman Empire. Post argues that this could not be the case since inter-lordly warfare within England was effectively banned in 1485'. Yet even if we accept the problematic claim that the English nobility was de-militarised once and for all in 1485 - rather than it being a more staggered and drawn-out process - Post's periodisation still fits squarely with our own narrative of the geopolitics of the Long $16^{\text {th }}$ Century (i.e. 1450-1650); the opening salvo being the fall of Constantinople in 1453. Post's historical claim about the timing of the English nobility's de-militarisation therefore supports - rather than contradicts - our own argument.
} 
(re)production instigating various forms of combined development. Consequently, while specific patterns of societal diversity may be contingent, 'the fact of this diversity itself is not'. ${ }^{18}$ This interactive dimension of social change imbues the historical process with a highly unpredictable character generating widely diverse but still theorisable outcomes. As such, societal difference should not be visualised as a result of the immanent properties of a society's endogenous development, but rather "dependent on a whole web of "necessary but contingent" interactions'. ${ }^{19}$

That Post views our structural analysis of the relationship between these ostensibly 'internal' and 'external' determinations as resting on 'contingent' arguments demonstrate the limits of Political Marxist conceptions of 'the international'. This is one of the reasons we share Perry Anderson's understanding of the origins of capitalism 'as a valueadded process gaining in complexity as it moved along a chain of interrelated sites'. ${ }^{20}$ This is a conception of capitalism's origins (and reproduction) that rejects - and seeks to go beyond - any spatiotemporally singular conception of causality: for example, the 'freeing' of the peasantry in the English countryside as the sole 'sufficient condition' for capitalism. ${ }^{21}$ Instead, our analysis points to the accumulation of many different 'necessary conditions' that once combined transform into a 'sufficient condition'. This de-centred or multi-perspectival conception of causality is integral to UCD, which entails a methodology capable of capturing the multiplicity of different causal factors - spatio-temporally variegated 'causal chains' - as internally and structurally related to one

\footnotetext{
18 Rosenberg 2006: 316.

19 Cooper 2013: 592; cf. Anievas 2016.

${ }^{20}$ Anderson 2005: 251.

${ }^{21}$ This was the case even for Marx who, despite all his attention to the expropriation of the direct producers, still did not view this process as in and of itself enough to produce capitalism, but rather only led to the 'dissolution' of existing production relations (HWCR: 215-222).
} 
another. In other words, UCD reconciles 'causal pluralism' (for lack of a better term) into a single theoretical framework. ${ }^{22}$ But once multiplicity and difference are established as potentially relevant conditions for capitalism's emergence, the question that obviously remains is: what is capitalism?

\section{Inside and Outside Capitalism}

One of the most interesting themes emerging from this symposium is the variations and differences in each contributors' conceptions of capitalism. Echoing a tendency we identified in $H W C R$, these conceptions of capitalism have polarised between the expansive and the narrow. For example, Dimmock, Post and Pal's capitalism is defined in the relatively narrow terms of the market-dependent capital relation, whereas Jairus Banaji's $(X X X)$ conception is more expansive - an entire epoch characterised by the 'increasing subordination of production to capital'. Significantly, such conceptions determine the spatial and temporal scope of our histories of capitalism.

In this section, we only briefly discuss the relative merits of each positions because, across them, we suggest there is a more fundamental and pressing concern. Between these divergent accounts is a shared problem - an inadequate theorisation of how capital relates to social relations that are irreducible to or historically independent of capital. There is much at a stake - both theoretically and politically - in how we approach this issue. For if the primary criterion in evaluating the utility of a social theory is its capacity in explaining 'really existing' history, then the problem of defining capitalism is not so much a question of how 'big' or expansive

${ }^{22}$ See Anievas and Nişancıoğlu 2016b. 
it is. It's a question of how well it captures and explains concrete sociohistorical processes.

In $H W C R$, we sought to demonstrate that the distinctive power of Marx's method lies precisely in how his explanations avoided the reduction of social reality into simplified and elegant abstractions. Instead, they took place by the expansion and complexification of the object under study. Marx's abstractions are heuristically useful by what elements of concrete reality are opened up for further exploration, not by what elements of reality they exclude. The progressive incorporation of evermore concrete determinations in turn entails a re-constitution of the original abstraction when applied to 'really existing' history. As such, the specific content of any given category is not rigidly fixed, but 'developed in their historical or logical process of formation'. ${ }^{23}$

We sought to apply a similar method in understanding the rise of capitalism wherein our original conception of $\mathrm{it}^{24}$ was progressively modified through our engagement with the history of capitalism's becoming. This involved incorporating into the definition of capitalism those wider assemblages of social relations and processes systematically geared toward the reproduction of the capital relation, but not reducible either historically or logically - to that relation alone. Such a conception entails differentiating between capital as a 'simple' transmodal social relation, on the one hand, and the historically-delimited capitalist mode of production, on the other. In so doing, it draws attention to the multiple ways by which the competitive accumulation of capital based on the exploitation of wage-labour - Davidson's preferred definition ${ }^{25}$ -

\footnotetext{
${ }^{23}$ Marx quoted in Sayer 1987: 21.

24 In the article out of which HWCR developed, we defined capitalism as 'a distinctive mode of production characterised by the systemisation of competitive accumulation primarily based on the exploitation of wage-labour' (Anievas and Nişancıoğlu 2013: 82fn24).

${ }^{25}$ Davidson taxes $(X X)$ us for not specifying precisely what we mean by the 'capital relation'. As this formulation should make clear, we understand the capital relation as being defined by two mutually constitutive and equally important dimensions: the 'vertical' relation between capital and labour, and;
} 
presupposes a broader array of social relations that makes this accumulation possible. These social relations can take various forms, such as coercive state apparatuses, (specific) ideologies and cultures of consent, or forms of power, domination and exploitation that are not immediately given in or derivative of the 'simple' capital relation, such as unwaged labour, slavery, debt-peonage, racism, patriarchy, etc. (see HWCR: 8-10, 220-221).

By contrast, the conception of capitalism offered by Post et al. takes place through an explicit abstraction from such relations. This results in a highly abstract model of capitalism predicated upon a singular spatiotemporal vantage point - the 16-17 ${ }^{\text {th }}$ century English countryside - which is then directly applied via the comparative method to additional case studies (e.g. the Low Countries, absolutist France, pre-Civil War United States, etc.) ${ }^{26}$ Brenner himself does not shy away from the fact that this conception of capitalism is essentially an 'ideal-type'27 built upon an analysis of the specific history of one and subsequently two countries (England and the Northern Netherlands). ${ }^{28}$

The problem with this conception of capitalism - shared by Post, Dimmock and Pal alike - is not simply that it is too 'thin'. The problem is that it doesn't get us very far in explaining either the actual history of capitalism or, perhaps surprisingly, its' historical specificity. As some Political Marxists have acknowledged, the simple existence of 'marketdependence is not a sufficiently precise criterion' to understand the

\footnotetext{
the 'horizontal' relations among many capitals (cf. Anievas and Nişancıoğlu 2016a: 76). Though we agree with Davidson that this process of competitive accumulation based on the exploitation of wagelabour constitutes the animating 'logic' of capital, we are at pains to emphasise how other social relations irreducible to the capital relation alone can also be constitutive of capitalism's 'logic of process'. 26 See Brenner 2001; Wood 2002; Post 2002; Teschke 2003.

27 See Brenner 1999: 44fn11.

28 The extent to which Brenner's study of the development of capitalism in the Low Countries simply reconfirmed or altered the model of capitalist property relations derived from his earlier analysis of the English case is open to debate: cf. Wood 2001; Post 2002; Davidson 2012: 415-416, 425; Knafo and Teschke 2017.
} 
historical determinacy of capitalist property relations. For, as Teschke and Knafo explain, 'market dependency was not an uncommon phenomenon, even in the late Middle Ages or the early modern era and is often read as a classical indicator of Smithian logics of market development'. ${ }^{29}$

The market dependency of economic agents (including wagelabourers) has been a structural feature of numerous societies prior to advent of capitalism in the early modern English countryside as well as in later societies Political Marxists correctly view as non-capitalist. ${ }^{30}$ Indeed, numerous recent historical works have provided invaluable analyses of the depth and degree of market-oriented activities in Medieval Europe ${ }^{31}$ in ways fundamentally challenging the Political Marxist notion of a 'selfsufficient' peasantry that would 'generally produce their own food' and only 'enter the market to supplement their "subsistence/safety first strategies"' ${ }^{32}$ In a passage directed in part as a critique of Brenner's work (but equally applicable to objections raised by Post and Dimmock), Jessica Dijkman argues that the 'idea that peasants were by nature subsistence-oriented and only turned to the market if they were forced to, has proved incorrect'. She also correctly rejects neo-classical economists' idyllic picture of 'peasants always ready and even eager to engage in specialisation and market-oriented production'. ${ }^{33}$ Acknowledging the fact

\footnotetext{
${ }^{29}$ Knafo and Teschke 2017: 5.

${ }^{30}$ Davidson (2003: 52-59) provides an example of the latter: the $17^{\text {th }}$-century Scottish Highlands where clans became market-dependent because the land's soil was too poor to grow crops, but nonetheless remained feudal. Regarding the former, Emigh (1998) shows how $15^{\text {th }}$-century Tuscany was characterised by all three of Brenner's conditions for the rise of agrarian capitalism - fixed-term leasing, market-dependent agents (including the prominent use of wage-labour), and landlords' inability to extract surplus by extra-economic means. Yet again these preconditions did not lead to the development of capitalist property relations.

${ }^{31}$ For an overview, see Perrson 2014.

32 Wood 2002: 55; cf. Post 2018: XX; Dimmock 2018: XX. A recent study by Dijkman (2011) provides a wealth of quantitative and qualitative data demonstrating that market-dependency was a pronounced structural feature of pre-16 $6^{\text {th }}$ century England, Holland, and Flanders. What is more, both Holland and Flanders were by 1500 characterised by a greater magnitude of market-dependent agents than capitalist England with respect to their structural dependence on purchasing their subsistence needs. Thanks to Jessica Dijkman for discussing these findings with us.

${ }^{33}$ Dijkman 2011: 314; see also, Persson 2014.
} 
that peasants could and did willingly enter market relations in ways that could unintentionally result in them becoming market-dependent over time does not - and emphatically should not - mean accepting a neo-Smithian model of capitalist development (see HWCR: 81-85). ${ }^{34}$

In fine, the Political Marxist conception of capitalism is both too abstract and insufficiently historicist. It therefore suffers from what Jairus Banaji's (XX) terms the problem of 'residualism': 'the tendency...to treat major strands in the earlier history of capitalism as a dress rehearsal for industrial capitalism'. He finds such a tendency within our work as well, noting how our use of primitive accumulation presupposes a capitalism waiting to happen. Similarly, Banaji argues that our deployment of UCD with its emphasis on multiple, amalgamated and co-existing forms or modes of production - further reproduces this residualism. Banaji suggests the missing Marxist history of merchant capitalism might offer 'a more coherent picture of the history of capitalism itself'. Specifically, he invokes Sven Beckert's Empire of Cotton ${ }^{35}$ as an example - albeit imperfect - of how such history-writing might take place through the 'biography of one product' (Banaji XXX).

\footnotetext{
${ }^{34}$ Post's critique of this claim in HWCM rests on identifying our position as exclusively resting on the historical work of Jane Whittle. Drawing on Dimmock's critique of this work, Post claims that Whittle focused on 'an extremely small sample of rural settlements in eastern England', and that her 'own research demonstrated exactly the opposite off her claims - that capitalist landlords ("gentry") were primary responsible for imposing market discipline on the emancipated peasants'. Irrespective of whether that may be the case, we in fact draw on a much larger body of historiographical literature in making these claims than Post is seemingly aware: see HWCR (309fns128 and 129) where we reference the works of Stephen Hipkin, R.W. Hoyle, Paul Glennie, Mavis E. Mate, R.M. Smith, J.R. Raftis, Mark Bailey, and Patricia Croot and David Parker. Moreover, whether Dimmock's (2014) own research on the town of Lydd and the surrounding marshlands of Eastern Kent is much more generalisable than Whittle's study is debatable. Indeed, Dimmock's main argument that capitalist development was set in train by English lords leasing out their demesnes at market-level rents between 1380 and 1420 is substantiated through an empirical analysis showing 'one institutional lord, Battle Abbey, doing so on Romney Marsh to one ambitious individual, Andrew Bate, in the 1430s' (French 2015: 1220, emphasis original). Capitalist Patient Zero perhaps, but unlikely to prove other studies of the emergence of English agrarian capitalism wrong since 'most of the evidence uncovered by the raft of local studies ignored by Brenner and disputed by Dimmock suggests that lords responded to the decline in labour in a number of ways' (French 2015: 1221).

35 Beckert 2014.
} 
We will return to Banaji's discussion of 'merchant capitalism', but first let us briefly respond to the charge of teleology. In particular, his argument that our use of terms such as 'transitional' certainly does demonstrate an unfortunate (on our part) presupposition of completion of something yet to come. And yet we would insist that not all causal arguments or, indeed, theorisations or conceptualisations of that causality, entail teleology. For it is necessary to presuppose the existence of an historical process or event if you are to trace what produced it. For example, our reading of the plantation as 'transitional' is very much part of a causal argument. That is, methods developed on the plantation would inspire and prefigure the sort of work-regimes of industrial capitalism. Such a prefiguration can only really be read after the fact.

But, moreover, the configuration of the 'transitional' here also helps us to outline a sociological (rather than historical) claim - that plantation slavery in the Americas was not the pristinely non-capitalist enterprise that it is often portrayed as by Marxists, ${ }^{36}$ but was deeply imbricated with social relations, processes and logics that would eventually become definitive of capitalism itself. Many of the work-regimes and disciplinary methods that would become characteristic of the industrial factory were pioneered on plantations. Furthermore, enslavement and the exploitation of slave labour remains a constitutive aspect of capitalist production today. In this respect, 'transitional' is perhaps a poor conceptualisation, and simply 'combination' more effective.

However, here we see the more substantive point that Banaji draws, which constitutes a fundamental challenge to the entire framework we use to understand the origins of capitalism - uneven and combined development (UCD). Specifically, UCD presupposes the co-existence and

${ }^{36}$ See, in particular, Dimmock $(X X)$ and Post's $(X X)$ contributions to this symposium. 
interrelation of various social forms, relations, and processes and, under certain circumstances, modes of production. The combination or amalgamation produced by interactions between these multiple forms in turn generates historical change. When situated within a specifically Marxist method, this would appear necessary to understanding modal transformations (such as the transition from feudalism to capitalism) not least if we assume that: a) the capitalist mode of production did not appear all at once, fully formed; b) there is some period of co-existence between different modes of production in periods of transformation, and; $c$ ) that such co-existence would be especially pronounced intersocietally.

For Dimmock, this is simply not a problem. Such is the resolute emphasis on the English countryside that processes happening elsewhere in the world simply do not matter. According to Dimmock (XX), the process of capitalist transformation in England had already been irreversibly completed by the 1620s, when plantations in the Americas were only just emerging as sites of accumulation. In this respect, the relations between England and the American plantations is solely a historical interest, wherein the social relations of plantation slavery are a contingent externality rather than theoretically integral to the functioning of capitalism. In Dimmock's own words (XX):

I disagree with the authors' contention that slavery and other forms of extraeconomic surplus extraction in the New World and later in India through colonial subjection were intrinsic to capitalism per se, although they are certainly to be included in the history of capitalism as it actually happened.

In turn, the world beyond England - 'elsewhere' - is theoretically significant inasmuch as it comparatively demonstrates the specificity and distinctiveness of the capital relation within England. This 'elsewhere', this 
externality is severed from developments in England itself, wherein the analysis of it - both in its own right and in its relation to England - recedes into irrelevance.

Against this, we are compelled to ask: at what point does the theoretical functioning of capitalism diverge from this history? Or put differently, what are the motivations behind not theorising these 'externalities' - colonial subjugation and enslavement, for example considering their empirical importance? What is the justification for their theoretical exclusion? Political Marxists have yet to offer an explicit answer to this question, but situated in their comparative approach we might be able to find one. We are often reminded that what motivates the Political Marxist approach is understanding the specificity of a particular path of development: why is it that English development diverged from Eastern European (Brenner) or French (Brenner, Wood) or American (Post)? Here societal difference represents an articulation of a historical problem (why society $A$ and not society $B$ ?).

Such an engagement with difference should be unsurprising for an approach that remains so wedded to internalist analysis, for what other relevance could differences between societies have other than comparison. By contrast, in HWCR societal alterity is understood in a different way - a solution to a very different problem: internalism (in each of the aforementioned guises). Societal difference is not only central to the theorisation of the intersocietal (unevenness) but also to grasping the interactive and relational significance of multiple forms of oppression and violence (combination) in the transition to and continuing reproduction of capitalism.

We consider this especially important because much of the violence and exploitation that capitalism was built upon was done so outside of Europe. Bringing in the experience of non-European societies helps 
demonstrate how many of the atrocities exported to an outside - 'zones of nonbeing'37 - have been integral to the functioning of capitalism. Our motivation for theorising this (rather than simply historicising it) is to show that these were not simply historical contingencies external to the otherwise pristine logic of capital accumulation. For Dimmock (XX) and others to suggest we therefore read capitalism as 'progressive' is strange to say the least. ${ }^{38}$ To leave the history of capitalism to Europe is to turn away from the atrocities committed by Europeans beyond their own lands and to turn away from the very worst of its horrors as a mode of production. But more pertinently, it is to include non-European histories to situate the struggles conducted by the oppressed globally against these processes firmly within history and theory as significant and central rather than irrelevant and marginal.

In contrast, Banaji $(X X)$ responds to the same issue by arguing that we should consider the problem less in terms of the transition from one mode of production to another, but more in terms of 'asking when and where production began to be subordinated to capital, and asking questions about the kind of capitals involved in those developments'. This would do away with the need to think about capitalism (and its' origins) in terms of 'co-existence' altogether. Similarly, Medved suggests (XX) there can be no 'independent' non-capitalist mode of production 'within' the capitalist world-system. As such, the question of origins is less about coexistence but more about how other modes of production are incorporated into and transformed by the capitalist world-system.

Banaji's reframing of the problem of capitalism's origins leads him to identify the importance of histories of merchant capital. It is here, he

\footnotetext{
${ }^{37}$ See Fanon (2008 2) and Gordon (2005)

${ }^{38}$ As Dimmock puts it (XX): 'It also seems to me an important point that, given the association of slavery and other atrocities with the making of capitalism, countries in the East would be queuing up claiming to have made a contribution to it.' See also Duzgun 2016.
} 
argues, that we might begin to find answers to the question in terms of this 'where and when'. Banaji produces a stunning list of histories for potential investigation, including capitalist activity spanning several millennia and the whole globe. He concludes by noting (XX): 'The Roman fine ware industry was organised on a capitalist basis, but it doesn't follow that Rome's economy was driven by capitalism in the sense in which one would normally understand this'.

In identifying these instances of capital beyond the historical (and geographical) scope of orthodox Marxist accounts, Banaji certainly challenges us (and others) to trace longer genealogies and lineages of practices typical of capitalism. Such a challenge is welcome, and such endeavours are certainly needed to deepen and expand the historiography of capitalism (Marxist or otherwise). Equally, we agree that a different kind of methodology or heuristic, which starts from a particular commodity or enterprise and traces its genealogy of production and circulation, might provide an effective method through which to conduct such research. We might add that this argument can be extended to not only how we understand capitalism but also to how we understand geopolitics or 'the international'. Taking a commodity or enterprise rather than 'the societal' as the unit of analysis might radically transform how we conceive of socio-political space and intersocietal interaction. Perhaps it might displace our own emphasis on UCD and, as such, we welcome such research endeavours as part of a continuing dialogue on the question of capitalism's origins.

In short, there is no denying that the 'biography of one product' can generate extremely fruitful and novel ways of understanding the operation of not only capitalism but of the world we live in or epochs past. Much recent work on global commodity chains, circulation and logistics reveals all kinds of operations that traditional Marxist analysis has missed, 
especially in line with the sort of congealed violence that lies behind commodity production. ${ }^{39}$ However, we would note that one of the remarkable insights of Marx - indeed the very basis for his whole theorisation of the capitalist mode of production - was grounded in the analysis of 'the commodity' in general. The biography of one product would perhaps expose some of the concrete operations of the commodity form, but it is only in 'abstraction', as an organising principle of social relations - 'relations mediated by things' - that Marx was able to capture both the logic and historical specificity of capitalism as a mode of production.

The advantages of this latter approach - the way in which the commodity-form organises and subsumes social life, rather than how social life organises the biography of a particular commodity - appear to us, for the purposes of grasping the historical specificity of capitalism, immensely greater. All of this being said, however, we see no reason why the two approaches should not be complimentary, so long as we acknowledge that they are doing different kinds of work historically and theoretically.

This becomes especially evident in Banaji's own research. In line with the partiality involved in the biography of the product, there is also a partiality associated with studying the history of capitalism from the perspective of certain enterprises and activities. There is no denying that there were commercial practices and capitalistic enterprises prior to the advent of the capitalist mode of production (see, e.g. HWCR: Chapter 7). And yet, in directly identifying these practices and individual enterprises with the capitalist mode of production itself, ${ }^{40}$ Banaji tiptoes rather precariously on a line that renders capitalism transhistorical. While Banaji

\footnotetext{
39 See, for example, Cowen (2015), Beckert (2014), Tsing (2009), Bonacich and Wilson (2008).

${ }^{40}$ A position that Banaji (2011: 58-61) has previously argued against.
} 
is no 'neo-Smithian', the method he advocates makes it difficult to theorise and then historically account for the radical historical specificity of capitalism - capitalism conceived of as a distinct social structure. It is telling that many of Banaji's concrete examples of capitalist activity rests on terms such as 'commerce', 'business', 'enterprise', 'money', 'industry', 'merchants', 'speculation', 'export', etc. The operation or practice of these forms is of course easy enough to find throughout history, as Banaji's impressive list demonstrates. Moreover, his work is an important corrective to the Political Marxist intuition that competition, markets, wagelabour, commerce, and finance have nothing to do with capital prior to capitalism, as Banaji argues.

But are these examples characteristic of the capitalist mode of production as such? Do they mark out its historical specificity? The issue is that the capitalist mode of production and indeed any of its variants commercial, merchant, industrial - simply appears everywhere for Banaji. The sort of practices, activities and relations Banaji identifies become so prevalent that all kinds of societies throughout history become in some way 'capitalist'. And as soon as we turn away from the possibility of multiple modes co-existing, these societies become unequivocally capitalist. Banaji, for example, cites the operation of capitalist industry in the Roman Empire. Was the Roman Empire capitalist? Perhaps this is not the point Banaji is making, but it does raise the stickier question of what was the Roman Empire.

There are only really two ways out of this dilemma. The first option is to claim that capitalism is itself transmodal or transhistorical; that there is nothing historically specific about the capitalist mode of production as it has essentially existed in varied and perhaps incomplete forms throughout most of history. Consequently, the very concept of a mode of production in general would dissolve. Would it make sense, for example, 
to talk meaningfully of feudalism or a feudal mode production, considering the extent of commercial activities that existed in medieval Europe? The second option is to acknowledge that certain practices - commerce, trading, finance, wage-labour, industry - have indeed existed prior to the capitalist mode of production but that their existence took on significantly different forms, in accordance with the relationship of these practices to other social practices and relations.

The question of what these 'other' social practices are is never broached by Banaji. For instance, in Banaji's account, the commerce of Genoa in medieval Europe operates hermetically sealed-off from all the other non-commercial activities taking place. The sorts of state support that Genoese commercial practices rested on were generated by numerous non-capitalist forms of extraction, exploitation, coercion, obligation and violence. These were not simply incidental to Genoese commerce but its very precondition and function. Genoese finance was in turn deployed primarily by absolutist states to conduct wars that had more to do with prestige, territorial accumulation, proselytising and statebuilding than they had to do with capital accumulation. This is precisely why a substantial portion of our theoretical preamble in Chapter 7 of HWCR builds a distinction between capital and capitalism, not as a dichotomy as Banaji reads it, but simply as different concepts.

To call these 'antediluvian' forms is not a dismissal - it is a simple acknowledgment of their historical existence but in contexts where they had not taken on the same power and significance they do under capitalism. In establishing this distinction, we are able to recognise the existence and histories of certain social relations and forms while also acknowledging the historically specific and different ways in which they are assembled, often in connection to other disparate social relations and forms. Indeed, once we acknowledge the co-existence of this wider array 
of social practices and relations - this wider assemblage - we need some sort of lexicon that might help us describe, explain and ultimately theorise it. The lexicon we use - UCD - is, in our minds, exceptionally well suited to this task.

In this regard, Medved asks (XX) why we do not draw on the concept of articulation as a way of negotiating this issue. In particular, he suggests that articulation offers a way of understanding co-existence that is more precise and specific than combination, which seems 'stretched' to the point of indeterminacy. There are a couple of reasons for our preferred use of combination. Firstly, such stretching is precisely the point, as our exposition of how general abstractions function in the previous section demonstrates. Secondly, rather than being indeterminate, we find in combination a thicker conception of co-existence than the one offered by articulation. More specifically, articulation provides a way of describing how different social forms co-exist and relate but offers no explanation of why they do. In contrast, combination already carries within a conception of interactivity derived from the concept of unevenness, wherein intersocietal determinations that generate the fusion of 'native' and 'foreign' are incorporated into its theoretical premises. It allows us to recognise variant social practices, with different historical rhythms, trajectories, and logics, while also tracing how these practices assemble, relate, subordinate, support and contradict each other.

Without incorporating such relations of difference and interaction into our theoretical premises, we run the risk of producing partial, onesided histories, starting from the vantage point of capital alone or a specific activity or relation therein (it is not for nothing that such Marxist approaches starts looking so Smithian). In contrast, Banaji's approach appears to take these pockets of capital as definitive of a mode of production and a partial history becomes constitutive and exhaustive of 
the (inter)societal whole. In turn, those components of social life that sit beyond these pockets are deemed irrelevant or left untheorised. Such partiality severs and discards the 'outside' of capital from our analysis of capitalism. In this respect, Banaji and Post/Dimmock/Pal - despite holding radically different conceptions of capitalism - are remarkably similar in their theoretical disregard for social relations that are not immediately reducible to the capital relation.

The contributions of feminist materialism, queer theory, black studies and postcolonialism ${ }^{41}$ have all shown how such acts of discarding not only erase histories and ongoing practices of violence and oppression that sit beyond the immediate operation of capital, but, moreover, mischaracterise capital (and capitalism) itself. These insights have shown how some Marxists have been too concerned with uncovering the internal logic and, in turn, the internal history of capitalism at the expense of ostensible 'externalities' - those relations and practices that sit outside of the pristine logic and history of capital.

Our key claim, following these insights, is that these 'externalities' matter, that those relations that sit 'outside' of capital can fundamentally shape, determine, change and destabilise capital. In our case, it is precisely this 'outside' that is central to the origins of capitalism itself; a set of non-capitalist histories which combine, enabling the forms of capital Banaji identifies (commerce, finance, industry, wage-labour, etc.) to take on an historically unprecedented power and social significance. It is this combination, this assemblage, that ultimately constructs the capitalist mode of production.

Once all of this is acknowledged, we need an alternative way of articulating societal difference and interaction that does not presuppose

\footnotetext{
${ }^{41}$ See e.g. Lowe (2015), Farris (2015), Chakrabarty (2009), Smallwood (2009), Wilderson (2003), Butler (1997), and Hartman (1997).
} 
either the capitalist world-system or core/periphery positions. UCD provides such an articulation and hence circumvents the reading of capitalist logics of intersocietal difference into non-capitalist contexts.

\section{Conclusion}

In our response to our interlocutors we have suggested that, firstly, Political Marxism remains situated in a internalist analysis due to a limited reading of 'the problematic of the international' and, secondly, that this problematic can only be properly addressed by incorporating the intersocietal into the ontological presuppositions of social theory. Thirdly, we argued that such an incorporation as a general abstraction is desirable, but only insofar as its status as transmodal does not do the work of historical explanation. Rather, UCD as a general abstraction opens new historical material for sociological analysis and poses new questions about how that historical material is handled. Such openings and questionings from the perspective of UCD, we argue, provides a better starting point for a theorisation and explanation of more concrete historical material, such as the origins of capitalism. So, fourthly, we argued that our understanding of the origins of capitalism demands some articulation of a multiplicity of social relations and how differences between these multiple social relations are theorised. We found across our interlocutors very different responses to this problematic insufficient, arguing instead that UCD is especially well-suited to articulating difference.

As we have argued, each of these disagreements rests on an impasse born of fundamental differences in how we understand the 'problematic of the international', the role of general abstractions, and the 
relationship between capital(ism)'s inside and out, respectively. We have also set out what we consider at stake in continuing to hold onto our own position in these series of disagreements. In particular, we have argued that a proper theorisation of 'the international' enables a richer, nonEurocentric historical sociology of the origins of capitalism. In turn, this alternative historical sociology offers new ways of thinking about capitalism in terms of a multiplicity of violences and struggles.

As this symposium well demonstrates, disagreements over the origins of capitalism will likely remain an animating force in Marxist debates. And so it should. Our purpose in writing HWCR was not to shut down debate or have the 'final word', but to open new lines of inquiry and research. In this respect, we can only hope that our own modest contribution acts to further stimulate - and perhaps even orient - future debates. We hope that it might in turn provide a means to elucidate various points of productive disagreement among different Marxist approaches that could act to sharpen their respective analyses.

\section{Bibliography}


Allen, Robert C. 2000. 'Economic Structure and Agricultural Productivity in Europe, 1300-1800'. European Review of Economic History 3: 1-45.

Anderson, Perry. 2005. Spectrum: From Left to Right in the World of Ideas. London: Verso.

Anievas, Alexander. 2016. History, Theory and Contingency in the Study of International Relations: The Global Transformation Revisited', International Theory 8(3): 468-480.

Anievas, Alexander and Kerem Nişancıoğlu. 2017. 'How Did the West Usurp the Rest? Origins of the Great Divergence over the Longue Durée', Comparative Studies in Society and History 59(1): 34-67.

Anievas, Alexander and Kerem Nişancıoğlu. 2016a. 'Why Europe? AntiEurocentric Theory, History, and the Rise of Capitalism', Spectrum: Journal of Global Studies, 8(1): 70-98.

Anievas, Alexander and Kerem Nişancıoğlu. 2016b. 'The Being and Becoming of Capitalism'. Progress in Political Economy. Available at: http://ppesydney.net/the-being-and-becoming-of-capitalism/.

Anievas, Alexander and Kerem Nişancıoğlu. 2015. How the West Came to Rule: The Geopolitical Origins of Capitalism. London: Pluto.

Anievas, Alexander and Kerem Nişancıoğlu. 2013. 'What's at Stake in the Transition Debate? Rethinking the Origins of Capitalism and the "Rise of the West"', Millennium: Journal of International Studies 42(1): 78-102. 
Banaji, Jairus. 2011. Theory as History. Leiden, NL: Brill.

Beckert, Sven. 2014. Empire of Cotton: A Global History. New York: Alfred A. Knopf.

Bieler, Andreas. 2016. 'How the West Came to Rule? Challenging Eurocenrism'. Progress in Political Economy. Available at: http://ppesydney.net/west-came-rule-challenging-eurocentrism/

Bonacich, E., \& Wilson, J. B. 2008. Getting the Goods: Ports, Labor, and the Logistics Revolution. Ithaca: Cornell University Press.

Braude, Richard. 2016. 'How the West Came to Rule'. Capital \& Class 40(1): 181-188.

Brenner, Robert. 2007. 'Property and Progress: Where Adam Smith Went Wrong'. In Marxist History-Writing for the Twenty First Century, edited by Chris Wickham, 49-111. Oxford: Oxford University Press, 2007.

Brenner, Robert. 2001. 'The Low Countries in the Transition to Capitalism'. Journal of Agrarian Change 1(2): 169-241.

Brenner, Robert. 1999. 'Competition and Class: A Reply to Foster and McNally'. Monthly Review 51(7): 24-44.

Brenner, Robert. 1986. 'The Social Basis of Economic Development'. In Analytical Marxism, edited by J. Roemer, 23-53. Cambridge: Cambridge University Press. 
Butler, Judith. 1997. 'Merely Cultural'. Social Text 52/53: 265-277.

Chakrabarty, Dipesh. 2007. Provincializing Europe: Postcolonial Thought and Historical Difference. Princeton: Princeton University Press, $2^{\text {nd }}$ Ed.

Cowen, Deborah. 2014. The Deadly Life of Logistics: Mapping Violence in Global Trade. London: University of Minnesota Press.

Davidson, Neil. 2012. How Revolutionary Were the Bourgeois Revolutions? Chicago.: Haymarket Books.

Davidson, Neil. 2010. 'Many Capitals, Many States: Contingency, Logic or Mediation?'. In Marxism and World Politics: Contesting Global Capitalism, edited by Alexander Anievas, 77-93. London: Routledge.

Davidson, Neil. 2003. Discovering the Scottish Revolution, 1692-1746. London: Pluto.

Dijkman, Jessica. 2011. Shaping Medieval Markets: The Organization of Commodity Markets in Holland, c. 1200 - c. 1450. Leiden, NL. Brill.

Dimmock, Spencer. 2017. 'The Eastern Origins of Capitalism?' Historical Materialism blog. Available at: http://www.historicalmaterialism.org/blog/eastern-origins-capitalism

Dimmock, Spencer. 2014. The Origin of Capitalism in England, 14001600. Leiden, NL: Brill. 
Duzgun, Eren. 2016. 'International Relations, Historical Sociology and the Eurocentrism Debate'. Spectrum - Journal of Global Studies 8(1): 6-20.

Emigh, Rebecca Jean. 1998. 'The Mystery of the Missing Middle-Tenants: The "Negative" Case of Fixed-Term Leasing and Agricultural Investment in Fifteenth-Century Tuscany'. Theory and Society 27(3): 351-375.

Fanon, Frantz. 2008. Black Skin, White Masks. London: Pluto

Farris, Sara. 2015. 'The Intersectional Conundrum and the Nation-State'. Viewpoint Magazine, 4 May. Available at: https://www.viewpointmag.com/2015/05/04/the-intersectionalconundrum-and-the-nation-state/.

French, H.R. 2015. 'Review: The Origin of Capitalism in England, 14001600, by Spencer Dimmock'. English Historical Review 130(546): 1219_ 1221.

Gordon, Lewis, R. 2005. 'Through the Zone of Nonbeing: A Reading of Black Skin, White Masks in Celebration of Fanon's Eightieth Birthday'. The CLR James Journal 11(1): 1-43.

Hartman, Saidiya. V. 1997. Scenes of Subjection: Terror, Slavery, and Self-making in Nineteenth-century America. Oxford: Oxford University Press

Knafo, Samuel and Benno Teschke. 2017. 'The Rules of Reproduction of Capitalism: A Historicist Critique'. Working Paper No. 12, University of Sussex. 
Lowe, Lisa. 2015. The Intimacies of Four Continents. Durham: Duke University Press.

Matin, Kamran. 2013. Recasting Iranian Modernity: International Relations and Social Change. London: Routledge.

Matin, Kamran. 2007. 'Uneven and Combined Development in World History: The International Relations of State-Formation in Premodern Iran'. European Journal of International Relations 13(3): 419-447.

Nişancıoğlu, Kerem. 2016. "Combination as "Foreign Policy": The Intersocietal Origins of the Ottoman Empire'. In Historical Sociology and World History: Uneven and Combined Development over the Longue Durée, edited by Alexander Anievas and Kamran Matin, 73-91. London: Rowman \& Littlefield.

Persson, K. G. 2014. 'Markets and Coercion in Medieval Europe'. In The Cambridge History of Capitalism, Volume 1: The Rise of Capitalism: From Ancient Origins to 1848, edited by L. Neal and J.G. Williamson, 225-266. Cambridge: Cambridge University Press.

Persson, K. G. 1991. 'Labor Productivity in the Medieval Economy: The Case of Tuscany and the Low Countries'. In Land, Labor and Livestock. Historical Studies in European Agricultural Productivity, edited by B. Campbell and M. Overton, 124-143. Manchester: Manchester University Press. 
Pijl, Kees van der. 2007. Nomads, Empires, States: Modes of Foreign Relations and Political Economy, Vol. I. London: Pluto Press.

Post, Charles. 2002. 'Comments on the Brenner-Wood Exchange on the Low Countries', Journal of Agrarian Change 2(1): 88-95

Rosenberg, Justin. 2006. 'Why Is There No International Historical Sociology?' European Journal of International Relations 12(3): 307-340.

Sayer, Derek. 1987. The Violence of Abstraction: The Analytical Foundations of Historical Materialism. London: Basil Blackwell.

Smallwood, Stephanie. E. 2009. Saltwater Slavery: A Middle Passage from Africa to American Diaspora. Cambridge: Harvard University Press.

Teschke, Benno. 2005. 'Bourgeois Revolution, State Formation and the Absence of the International'. Historical Materialism 13(2): 3-26.

Teschke, Benno. 2003. The Myth of 1648: Class, Geopolitics, and the Making of Modern International Relations. London: Verso.

Tsing, Anna. 2009. 'Supply Chains and the Human Condition'. Rethinking Marxism 21(2): 148-176.

Wickham, Chris. 2008. 'Productive Forces and the Economic Logic of the Feudal Mode of Production'. Historical Materialism 16(2): 3-22.

Wilderson, Frank B., III. 2003. 'Gramsci's Black Marx: Whither the Slave in Civil Society?'. Social Identities 9(2): 225-240. 
Wood, Ellen Meiksins. 2002. 'The Question of Market Dependence'. Journal of Agrarian Change 2(1): 50-87. 